\title{
Understanding People's Motives for visiting Public Green Spaces in Accra to aid the Development of Urban Greenery in Ghana
}

\author{
Jackson G. K. Abankwa ${ }^{1 *}$ Ninnette Quaofio $^{1}$ \\ ${ }^{1}$ 'School of Architecture and Design, Central University, P. O. Box 2305, Tema, Ghana \\ *Emails of the corresponding author: jgkabankwa@gmail.com; jabankwa@central.edu.gh
}

\begin{abstract}
In the recent past, the empirical evidence of the potential benefits urbanites derive from the use of urban green space has received increased attention. However, not much research has been done on the use of urban green areas, especially in developing African countries like Ghana. This paper determines the motives of the public for visiting urban green spaces and the factors that influence their perception of the quality of urban natural areas in Ghana, using Accra, the capital city of Ghana, as the case study. The questionnaire method was used for the collection of quantitative data from the public. The findings revealed "socialising", "mental wellbeing or restitution" and "spirituality" as the significant motives of residents for the usage of green spaces in Accra. The results further show that the key factors that influence the public's perception of the quality and utilisation of green spaces in Accra are the spaces' physical features, conditions of facilities, sanitation and security concerns. The outcome of the research revealed a thought-provoking perspective for future research on "spirituality" as significant users' motivation for visiting urban green spaces since the "spirituality" factor is deficient in literature. The findings from this study are critical for policy-makers, urban designers and landscape architects to understand the vital motives of users and the factors that influence the use of green spaces, to improve the development and management of urban green areas in Ghana and other developing countries.
\end{abstract}

Keywords: Urban Green Space, motives, greenery, Accra, Ghana

DOI: $10.7176 / \mathrm{DCS} / 10-8-08$

Publication date:August $31^{\text {st }} 2020$

\section{Introduction}

The integration of natural green spaces into the urban landscape has progressively become crucial for the quality of life and the sustainability of metropolitan areas (Chiesura, 2004). In addition to the environmental and economic usefulness, urban green spaces provide social, psychological, and human health benefits to urbanites. (Arnberger, 2006; Gaodi et al., 2010; Byrne \& Sipe, 2010). Global research on urban green spaces has, therefore, been extensive covering issues such as design, advantages, values, ecological equity, etc., but not so much on users' motivations for visiting public urban green spaces (Byrne \& Wolch, 2009). Within the broader context, Henderson and Bialeschki (2005) confirmed that the social dimensions of urban green spaces are under-researched.

According to the African Green City Index (2011), there is a knowledge gap in the motives that facilitate practical urban green space usage, especially in Sub-Saharan Africa, and for that matter, Ghana. There is, therefore, the need to comprehend the public's intents for visiting, and the factors that influence their perception of the quality of, public green spaces in Ghana. The significance of the study is, thus, rooted in the fact that the predominant research findings from advanced countries on the development and use of urban green spaces may not necessarily be the same in the Ghanaian context. This paper provides a constructive basis for increased development of green spaces in Ghana. It also enables managers of green spaces and urban designers to formulate targeted strategies to stimulate the use of urban green areas in Ghana.

\section{Overview of Literature}

\subsection{Benefits of visiting Urban Green Spaces}

Empirical research findings confirm the multi-functional roles and unique benefits of urban green spaces to urban dwellers (Arnberger, 2006). These benefits, which are both tangible and intangible, are categorised into social, psychological, human health, environmental, and economic services (Gaodi et al., 2010; Byrne \& Sipe, 2010).

The presence of trees and grass in green spaces encourage the use of outdoor spaces. It creates positive social benefits such as stimulation of social cohesion, fostering of family interactions, neighbourhood and community ties (Kuo et al., 1998). By using green spaces to formally and informally bring people from different cultural and 
socio-economic backgrounds together, urban green spaces increase social unification and communication among neighbours (Coley et al., 1997). Urban green spaces are preferred outdoor community spaces for passive and active recreation, special events like gathering and for organising public and private events and traditional festivals or cultural celebrations, funerals and carnivals (Chiesura, 2004). The religious significance of urban green spaces has been observed in many communities, such as the Hindus and Melanesians (Thaman (1987). The social dimension of urban green space creates other positive benefits such as providing safe places for children to play (Chiesura, 2004) and promoting environmental responsibility that enhances the quality of life (Hussain, 2014). Green spaces are also ideal spaces for leisure for all age groups and positive behavioural development for children (Chiesura, 2004; Quagraine, 2011).

Urban green spaces, especially those with trees, manicured landscapes, sidewalk gardens, flowers and the associated aroma, can produce strong nourishing psychological feelings, reduce stress and improve moods (Nielson \& Hansen, 2006). A park experience achieves these feelings because greenery enhances contemplativeness, rejuvenates urban residents, and provides a sense of peacefulness and tranquillity (Ulrich, 1984; Beaney, 2009). Green spaces are a potent source of restorative state of mind, and they also provide serene milieu specifically for visitors to reflect, contemplate, meditate and achieve a feeling of harmony with the natural ambience and for general spiritual experiences, including feeling closer to God (Chiesura, 2004; Roos et al., 2011). People who visited green spaces, therefore, feel happier and experience improved moods (Beaney, 2009). The therapeutic function of natural environments has been confirmed by Ulrich's (1984) assertion that the chances of faster recovery of hospitalised patients with direct visual access to outdoor greenery were much higher than those confined to only buildings.

In addition to the psychological inspirations, the regenerative and rejuvenation benefits users derive from urban green spaces positively affect their health and wellbeing. Urban green areas provide opportunities to people of all ages for physical activities such as walking, cycling or riding. These activities generally result in people being more physically active with consequential improved human health (Humpel et al., 2002; Irvine et al., 2013). In Sheffield, United Kingdom, older people generally like to walk in the woodlands because the natural environment gives them health and spiritual benefits (Jorgensen \& Anthopoulou, 2007). The association between positive human wellbeing and green space is comprehensively documented in academic studies (e.g. Humpel et al., 2002; Nielsen and Hansen, 2007; Nieuwenhuijsen et al., 2014; and Jonker et al., 2014).

\subsection{Users' Motives for visiting Urban Green Spaces}

There is a wide variety of people's motives for visiting urban green spaces, which include socialising, recreation, relaxation, exercising, tourism, encountering nature, education, being with companion animals, escaping from the city and for solitude (Byrne \& Wolch, 2009). The facility's physical features, its infrastructure and accessibility, the community within which the green space is sited, the distance from the users' residences and the recreational activities offered by the green space, shape the motive for the use of green spaces (Thompson, 2002; McCormack et al., 2006).

Also, Sasidharan et al. (2005) and Özgüner (2011) posited that there are cultural differences in people's motives for visiting urban green spaces. For instance, in Denmark, the significant purposes for visiting urban green spaces are socialising, enjoying the weather, resting and restitution (Schipperrijn et al., 2010; Peschardta et al., 2012). Attending events, walking and dog-walking, enjoying the environment, getting away from it all and socialising are the main motives of Brtish park users (Dunnet et al., 2002). Whereas the purposes of urban green space users in Budapest relate mainly to walking, relaxing with children and participating in sporting activities, urban green spaces in Turkey are used primarily for picnicking, resting and relaxing (Özgüner, 2011). The reasons for visiting urban green areas in the USA also relate to sporting activities, walking, jogging, cycle-ridding, socialising and relaxing (Lee \& Kim, 2015).

According to Lee and Kim (2015), in the Republic of Korea, the key motives of urban green space users are linked to relaxing, walking, socialising, active sports and exercising. Similarly, the most commonly cited reasons for visiting green spaces in the Asian countries of Hong Kong, Malaysia and Singapore are to workout and to relax (Hussain \& Abdul Mohit, 2005). The majority of users in the Republic of South Africa visit urban green spaces for recreation and psychological reasons (Ward et al., 2010). On the other hand, relaxing, listening and observing nature are the principal motives for visiting urban green spaces in Holland, in addition to the spiritual dimension relating to "reflection, meditation and a general feeling of harmony between oneself and the surrounding" (Chiesura, 2004, p.135). 
In summary, the various motives of diverse humanities for using urban green spaces fall into six broad categories. These are "enjoying the environment, socialising, getting away from the hassle and bustle of the city, walking activities including dog-walking, passive or informal enjoyment, active enjoyment including sports and attending events" (Swanwick et al., 2003, p.103). As noted by Chiesura (2004, p.132), "peoples motives to visit natural areas and the various activities they carry out reflect the demands people place on natural areas, and the needs they expect to be fulfilled". Understanding the motives for visiting Accra's green spaces is crucial in formulating the appropriate design and management strategies for the effective development of urban green spaces in the city.

\subsection{Demographic Factors influencing the use of Urban Green Spaces}

The use of any urban green area is directly influenced by the personal attributes of users which differ according to age, gender, ethnicity and cultural background, education and socio-economic status (Chiesura, 2004; Kemperman and Timmermans, 2008; Byrne \& Wolch, 2009; Central Park Conservancy, 2011; Qureshi et al., 2013).

Peoples' motives for vising and experiencing green spaces are influenced by their age group (Chiesura, 2004). Natural settings provide a wide-ranging and inspiring environment for children to play, learn and experience nature (Quagraine, 2011). Teenagers and young people in their early twenties, who tend to focus on intimacy and friends, socialise more closely with their peers in green spaces rather than with their families. In contrast, people aged between 31 and 40 years typically have children and tend to choose activities like playing games and relaxing in urban natural areas (Lee, 2011). Young adults under 24 years old and matured healthy adults aged between 55 years and 64 years, who have no family commitments, are associated with cycling in urban green spaces (Thompson et al., 2005). The development and operation of appropriate urban green spaces are, therefore, highly dependent on thoughtful differences in the age group of potential users.

Gender influences the use of green spaces, mainly in terms of personal safety. Virden and Walker (1999) deduced that women perceive green spaces as potential dangerous spaces and feel more threatened in these spaces than men. Their fear could stem from stronger feelings concerning natural threats such as wild animals, remoteness, or the unknown. Besides safety, women have the perception that green spaces do not provide adequate infrastructure for leisure opportunities and their personal needs in terms of the location of washrooms, walkways, signage, security and lighting (Valentine, 1991). Compared to men who participate in active and vigorous activities in natural woodlands, women like to be in traditional managed green spaces where they can be with friends or families (Hoet et al., 2005). Women's engagement in recreational activities is influenced by their social roles and family obligations, unlike men who tend to have ample discretionary time (Aspinall et al., 2004).

Socio-cultural backgrounds of the users have been associated with differences in the patterns of use and preference for recreational areas, activity participation, in addition to the meanings and values ascribed to urban green spaces (Sasidharan et al., 2005). For instance, in Korea, socially based activities such as 'family togetherness' and 'being with friends' are associated with users of the National Park (Shin et al., 2001), whereas in Malaysia urbanites prefer organised recreational events in local parks (Hussain \& Abdul Mohit, 2005; Hussain, 2014). Makworo and Mireri (2011) noted that Kenyan park users visit parks mainly to participate in passive recreation and to relax, but Arnberger (2006) concluded that the motives of Austrians are primarily to engage in active activities such as vigorous walking and dog walking, cycling and jogging. African-Americans' reasons related to undertaking sport and organised recreation activities in addition to sitting and walking in urban green spaces, whereas Latinos engage in sedentary and informal social events such as picnicking, camping and hiking (Sasidharan et al., 2005). Scottish green space users participate in both passive activities, such as viewing hills and animals and bird watching, and active activities like jogging and dog-walking (Thompson et al., 2005).

The educational level and the socio-economic status of people influence the types and locations of green space they visit and the regularity of their visits (Kemperman \& Timmermans, 2008). For instance, from a study on the factors influencing the use of urban green spaces in Denmark, Schipperrijn et al. (2010) concluded that individuals with lower levels of education visited urban green areas less often than those with higher education levels. Kay (2000) opined that very few people of the upper socio-economic groups use public urban green spaces because they are disposed to wide-ranging leisure activities which usually take place in better and wide geographically distributed green spaces. In contrast, the recreational activities of the lower socio-economic groups are less diverged. Their activities typically involve families and other relatives and usually take place within neighbourhood green areas. Moreover, the lower socio-economic groups tend to lack the opportunities to access the environments in different locations available to the upper class or bourgeoisie. 


\section{Study Area, Materials and Methods}

\subsection{The Study Area}

The study area is Accra, the capital and the largest city in Ghana. Accra was delineated for the study because the population, environment and cultural characteristics and physical development of the city are typical of Ghana's urban areas.

The population of Accra grew from 16,267 in 1891 to 61,558 in 1931, then to 624,091 in 1970 and to 964,879 in 1984 (Ahuno, 1992). In 2000, the population of Accra was 1,658,937 (Apt, 2002), but it increased to 1,665,086 in 2010 with an urbanised population of up to 90 per cent (Ghana Statistical Service, 2013). The population of the larger metropolitan area, Greater Accra Metropolitan Area, is 3,655,560 (Ghana Statistical Service, 2014). At a projected average annual growth rate of $4.59 \%$, the UN-Habitat (2014) predicts the population of Accra to increase to $4,228,000$ by 2025 . Accra has the second-highest population density of 11,700 persons per square kilometre compared with the index average of 4,600 and second only to Cairo out of the fifteen (15) major African cities surveyed by the African Green City Index (2011). The extraordinary population density, emanating from migration and urbanisation, has stretched the capability of the city's policies to contain sprawl and to protect open green spaces. The suburbs that have mushroomed at the edges of the city are generally developed with little or no public green spaces (African Green City Index, 2011).

Public green spaces in Accra are few and generally in deplorable conditions (Arku et al., 2016). The significant identifiable open greens spaces in Accra are the Achimota Forest, Legon Botanical Gardens and Efua Sutherland Children's Park (Town and Country Planning Department, 2001). Besides, there are some privately owned and managed green spaces in the metropolis that are open to the public, such as Rufus Green Park, Timora Gardens, Marvels Gardens, Matelo Recreational Centre, Cleaver House Gardens and Top Venue Gardens. These natural areas have serene and beautiful environments with fountains, lawns, trees and flowers. The scarcity of public green spaces in Accra necessitates the need to explore the motives for the use of existing ones to provide a basis for their revitalisation and the development of new ones.

\subsection{Materials and Methods}

The questionnaire method, which is considered as the best measure to define and deeply understand the attitudes, perceptions, expectations and preferences of large samples (Cooper and Schindler, 2006), was used for the collection of quantitative data from the public. The questionnaire, comprising mainly 'closed' questions and a few 'open-ended' ones, was based on theoretical concepts in the existing literature that were modified to meet the study's aim and objectives and to respond to the research questions. The questionnaire survey aimed to identify the public's motives for using urban green spaces and the factors that influence their perception of urban green space quality and decision to visit green spaces in Accra. Besides being better suited to the large sample, the selfadministered questionnaire method afforded the respondents adequate time to consider their answers before responding since they could be limited in scope and knowledge in the subject area (Mitra \& Lankford, 1999).

Simple random sampling, a probability sampling technique, was used in selecting the sample for the questionnaire survey, which comprised both visitors and non-visitors of the green spaces in the city. An approximate sample size of 385 was computed for the city-wide population based on the following formula proposed by Birchall (2014), with $\mathrm{z}=1.96$ and $\mathrm{e}=10 \%$ of the population standard deviation.

$$
\mathrm{s}=(\mathrm{z} / \mathrm{e})^{2}
$$

Where:

$$
\begin{aligned}
& \mathrm{S}=\text { the sample size. } \\
& \mathrm{z}=\text { a number relating to the degree of confidence ( } 1.96 \text { for } 95 \% \text { confidence) } \\
& \mathrm{e}=\text { the acceptable error, measured as a proportion of the standard deviation }(10 \%) \\
& \mathrm{S}=(1.96 / 0.1)^{2} \\
& \mathrm{~S}=384.16
\end{aligned}
$$

In other words, $s \geq 384.16$. Therefore, a minimum sample size of 385 was adopted for the questionnaire survey. On the assumption that about $5 \%$ of the survey forms could be incomplete or invalid for analysis, 400 questionnaires were distributed.

To ascertain the public's motives for using urban green spaces, 5-point Likert scales asking the degrees of agreement ranging from 'Strongly Disagree' and 'Disagree' on the one end to 'Strongly Agree' and 'Agree' on 
the other, with 'Neither Agree nor Disagree' in the middle (Bertram, 2007) was used. Respondents were required to indicate the extent to which they agreed or disagreed with identified factors relating to motives for the use of green spaces in Accra. Similarly, a Likert scale with values from 1 to 5 was used to rate the factors that influenced their use of urban green areas by specifying 'Extremely Important', 'Very Important', 'Undecided', 'Important', or 'Not Important' categories.

The survey was conducted on 400 people comprising 200 users in twenty (20) green space sites in the city and 200 households surveyed in their homes. The household survey was based on a "stratified multistage cluster design" (Yansaneh, 2005), a probability sample method for clustering questionnaires. As a first step, the nine (9) Municipal, Metropolitan and Districts Assemblies (MMDAs) were adopted as the Primary Sampling Units (PSUs) because of their distinct statutory boundaries. Geographically clustered dwelling units or households were selected from twenty (20) neighbourhoods sampled out of the MMDAs as the second-stage component. The "Skip Interval of two Households" technique recommended by List (2005) was used to sample households within the various neighbourhood clusters. Finally, ten (10) persons were selected within each of the twenty (20) sampled neighbourhoods as the ultimate sampling units at the third stage. The Kish Grid, a probability sampling model (Kish, 1965), was used to select one person as a respondent per household systematically. At the end of the survey, the targeted 200 sample size each for visitors at green space sites and the door-to-door survey was attained.

Open-ended questions in the questionnaire were content analysed while quantitative data analysis was done by the use of Statistical Package for Social Science Software (SPSS) Version Twenty (SPSS V. 20). Descriptive statistics, regression analysis, analysis of variances (ANOVA), factor and frequency analysis and non-parametric tests were performed to present the findings. Besides, the ordinal demographic variables were analysed with the use of Spearman rank-order correlation (William, 1975).

\section{Findings and Discussions}

\subsection{Demographic Characteristics of Respondents}

The variables related to the backgrounds of the respondents are detailed in Table 1, and the conclusions of the analysis of the ordinal demographic variables using Spearman rank-order correlation are presented in Tables 3 and 4.

Table 1: Demographic Characteristics of Respondents

\begin{tabular}{|l|c|c|}
\hline \multicolumn{1}{|c|}{ Characteristics } & Frequency & $\begin{array}{c}\text { Percentage } \\
\text { (\%) }\end{array}$ \\
\hline Gender & 200 & $50.0 \%$ \\
\hline Male & 200 & $50.0 \%$ \\
\hline Female & & \\
\hline & & \\
\hline Marital status & 270 & $67.5 \%$ \\
\hline Single & 102 & $25.5 \%$ \\
\hline Married & 12 & $3.0 \%$ \\
\hline Age Group & 136 & $34.0 \%$ \\
\hline Under 18 years & 158 & $39.5 \%$ \\
\hline $18--24$ years & 60 & $15.0 \%$ \\
\hline $25-34$ years & 26 & $6.5 \%$ \\
\hline $35-44$ years & & \\
\hline $45-54$ years & & \\
\hline
\end{tabular}




\begin{tabular}{|c|c|c|}
\hline 55-64 years & 6 & $1.5 \%$ \\
\hline Over 65 years & 2 & $0.5 \%$ \\
\hline Characteristics & Frequency & $\begin{array}{c}\text { Percentage } \\
(\%)\end{array}$ \\
\hline \multicolumn{3}{|l|}{ Employment Status } \\
\hline $\begin{array}{l}\text { Government } \\
\text { organisations }\end{array}$ & 40 & $10.0 \%$ \\
\hline $\begin{array}{l}\text { Private } \\
\text { organisations }\end{array}$ & 140 & $35.0 \%$ \\
\hline Self-employed & 70 & $17.5 \%$ \\
\hline Unemployed & 30 & $7.5 \%$ \\
\hline Retired & 2 & $0.5 \%$ \\
\hline Housewife & 12 & $3.0 \%$ \\
\hline Student & 106 & $26.5 \%$ \\
\hline \multicolumn{3}{|c|}{ Monthly Income (GHS) US\$1.00 = GHS5.00 } \\
\hline Below 500 GHS & 178 & $44.5 \%$ \\
\hline 501-1500 GHS & 102 & $25.5 \%$ \\
\hline $1501-2500 \mathrm{GHS}$ & 68 & $17.0 \%$ \\
\hline $2501-3500 \mathrm{GHS}$ & 24 & $6.0 \%$ \\
\hline $3501-5000 \mathrm{GHS}$ & 24 & $6.0 \%$ \\
\hline
\end{tabular}

Source: Authors' Fieldwork 2020

\subsection{Frequency and preferred hours and days of visits to Green Spaces}

The frequency of visits to urban green spaces is described using terminologies adapted from Dunnett et al. (2002). 'Daily' refers to the use of a green space once a day, and 'weekly' is defined as one visit per week. 'Monthly' means a visit per month and 'every three months' means one visit every three months. 'Occasionally' is described as one visit once a year or less. The findings from the study indicated that the majority ( $83 \%)$ of the respondents visited green spaces in Accra only occasionally. Within every three months, $8.00 \%$ of the respondents visited green space once, while $5.0 \%$ did so monthly. The minority, $4.0 \%$ and $1.0 \%$ visited green spaces weekly and once every six months, respectively.

The majority $(83 \%)$ of the urban green space users visited green spaces occasionally, i.e. they only undertook a visit once a year or less, while only $4.0 \%$ used green spaces once every week. The results were anticipated since customarily visiting urban green areas is not a priority among Ghanaians, compared to participating in organised events or visiting shopping malls. Besides, the shortage of green spaces in the city denies residents the opportunity to use them for various activities regularly. This pattern of green space usage is in sharp contrast with what pertains in cities in the advanced countries where urban green spaces are heavily patronised throughout the week for various reasons, primarily for human health benefits (Schipperrijn et al., 2010; Peschardta et al., 2012). 
Table 2: Urban Green Space Users' preferred days and hours of visitation

\begin{tabular}{|c|c|c|c|c|c|c|c|}
\hline \multirow{2}{*}{$\begin{array}{c}\text { Preferred } \\
\text { Day(s) for } \\
\text { visiting Urban } \\
\text { Green Spaces }\end{array}$} & \multicolumn{7}{|c|}{ Hours of the day respondents typically visit green spaces (GMT) } \\
\hline & $\begin{array}{c}\text { Morning } \\
\text { (6:00 to } \\
9: 59)\end{array}$ & $\begin{array}{c}\text { Mid-day } \\
(10: 00 \text { to } \\
11: 59)\end{array}$ & $\begin{array}{c}\text { Afternoon } \\
(12: 00 \text { to } \\
14: 59)\end{array}$ & $\begin{array}{c}\text { Evening } \\
(15: 00 \text { to } \\
17: 59)\end{array}$ & $\begin{array}{l}\text { Night } \\
\text { (After } \\
\text { 18:00) }\end{array}$ & Total & $\%$ \\
\hline Public Holidays & 8 & 25 & 53 & 17 & 2 & 105 & 34.20 \\
\hline Weekdays & 0 & 10 & 0 & 3 & 4 & 17 & 5.54 \\
\hline Weekends & 28 & 22 & 101 & 10 & 3 & 164 & 53.42 \\
\hline $\begin{array}{l}\text { Free/casual } \\
\text { periods }\end{array}$ & 6 & 3 & 12 & 0 & 0 & 21 & 6.84 \\
\hline Total & 42 & 60 & 166 & 30 & 9 & 307 & 100.00 \\
\hline$\%$ & 13.68 & 19.54 & 54.07 & 9.77 & 2.93 & 100.00 & \\
\hline
\end{tabular}

Source: Authors’ Fieldwork 2020

As shown in Table 2, the majority of the users visited the green spaces during weekends (53.42\%) and public holidays (34.20\%). Across the preferred days of visitation, $54.07 \%$ of respondents used the green spaces in the early afternoons between 12:00 and 3:00 GMT, while about 20\% visited around mid-day (10:00 to 12.00 GMT). The proportion of the respondents that visited green spaces in the morning, evening and night are approximately $14 \%, 10 \%$ and $3.0 \%$ respectively. This occurrence is explained by the fact that people mainly visit green spaces to socialise and to participate in public events, such as recreation, religious activities, and family picnics, that are typically organised from mid-day to afternoons during weekends and public holidays.

\subsection{Users' Motives for visiting Urban Green Spaces in Accra}

Section B of the questionnaire comprised ten (10) statements corresponding to green space users' motives for using urban green spaces in Accra. The sample sizes, means and standard deviations of each of the reasons for using the green spaces in Accra are presented in Table 3.

With the highest mean score of 4.63, the respondents indicated that the most important reason for visiting green spaces in Accra was "to do something together with family/children or friends, e.g. picnicking", as indicated in Table 3. The results revealed "to socialise at organised events, such as parties, weddings, funerals, club meetings, picnics, public events", with a mean score of 4.22, as the second main reason for visiting green spaces. The third and fourth highest-rated aims for visiting urban green spaces the findings exposed are "to rest, relax and reduce stress by escaping from the hustle and bustle of the city or getting away from daily tasks", and "to participate in religious activities such as prayers, retreats, worshipping", with mean scores of 4.06 and 4.00, respectively. 
Table 3: Descriptive Statistics of Motives for visiting Urban Green Spaces

\begin{tabular}{|c|c|c|c|c|}
\hline $\mathbf{S} / \mathbf{N}$ & Motives for using Urban Green Spaces & $\mathbf{N}$ & Mean & $\begin{array}{c}\text { Std. } \\
\text { Deviation }\end{array}$ \\
\hline A. & $\begin{array}{l}\text { To sport or to exercise to keep in shape (cycling, } \\
\text { walking, jogging, aerobics, etc.). }\end{array}$ & 307 & 3.05 & 1.352 \\
\hline B. & $\begin{array}{l}\text { To do something together with family/children } \\
\text { or friends, e.g. picnicking. }\end{array}$ & 307 & 60 & 0.735 \\
\hline C. & $\begin{array}{l}\text { To observe, experience and learn from the } \\
\text { elements of nature (flora and fauna). }\end{array}$ & 307 & 3.50 & 1.300 \\
\hline D. & $\begin{array}{l}\text { To reflect, contemplate and meditate, } \\
\text { renew/rejuvenate and for inspiration. }\end{array}$ & 307 & 3.85 & 1.104 \\
\hline E. & $\begin{array}{l}\text { To participate in religious activities such as } \\
\text { prayers, retreats, worshipping, etc. }\end{array}$ & 307 & 00 & 1.167 \\
\hline F. & $\begin{array}{l}\text { To socialise at organised events (parties, } \\
\text { weddings, funerals, club meetings, picnics, old } \\
\text { school reunion, public events, etc.). }\end{array}$ & 307 & 4.22 & 1.092 \\
\hline G. & $\begin{array}{l}\text { To have recreation or leisure by cycling for } \\
\text { pleasure, walking with companions or dogs, } \\
\text { photographing, playing musical instruments, etc. }\end{array}$ & 307 & 3.78 & 1.267 \\
\hline $\mathrm{H}$. & $\begin{array}{l}\text { To rest, relax and reduce stress by escaping from } \\
\text { the hustle and bustle of the city or getting away } \\
\text { from daily tasks. }\end{array}$ & 307 & 4.06 & 1.135 \\
\hline I. & To have privacy and intimacy & 307 & 3.56 & 1.301 \\
\hline $\mathrm{J}$. & $\begin{array}{l}\text { To enjoy the weather, to sun-bath and or get } \\
\text { fresh air. }\end{array}$ & 307 & 3.88 & 1.087 \\
\hline & Valid N (listwise) & \multicolumn{3}{|c|}{400} \\
\hline
\end{tabular}

Source: Authors' Fieldwork 2020

Other motives for using urban green spaces, are "to enjoy the weather and to get fresh air (3.88)", 'to reflect, contemplate and meditate, renew or rejuvenate and for inspiration" (3.85), and "to have recreation or leisure by cycling, walking with companions, photographing, playing musical instruments", etc. (3.78). The respective mean scores of "to have privacy and intimacy", "to observe, experience and learn from the elements of nature" and "to sport or to exercise to keep in shape (cycling, jogging, and aerobics, etc.)", were 3.56, 3.50 and 3.05, indicating that they are minor motives for respondents' usage of the green spaces in Accra.

In measuring the correlation between respondents' characteristics and their motives for visiting green spaces, the findings did not reveal any significant relationships between variables such as users' age, marital status, income levels, and employment status and the four (4) significant motives for using green spaces in Accra. This finding is contrary to previous postulations that the personal attributes of users, such as age, gender, education and socioeconomic status, disability and physical fitness, directly influence the use of urban green spaces (Chiesura, 2004; Kemperman \& Timmermans, 2008; Byrne \& Wolch, 2009; Central Park Conservancy, 2011; Qureshi et al., 2013). 
However, gender and time of the visit of users have a significant positive relationship with the four (4) significant motives for green space visitation, as indicated in Tables 4. Similar to findings by Aspinall et al. (2004) and Hoet et al. (200), there is a significant positive correlation between the motives of females for green space visitation and socialisation, such as using green spaces "to do something together with the family, children or friends", and "spirituality", or "participation in religious activities such as prayers, retreats and worshipping". On the other hand, males' motives relate to restitution like "resting and reducing stress by escaping from the hustle and bustle of the city or getting away from daily tasks". Furthermore, the findings indicate a significant relationship between users' preferred time of visits to green spaces and their motives. Users with spirituality and socialisation motives visit green spaces mainly between 6.00, and 10.00 GMT. Conversely, those with restitution motives tend to visit the green spaces in the afternoons.

Table 4: Correlations between Control Variables and Respondents' Characteristics

Table 4A: Correlations between Users' Motive 'To do something together with family/children or friends' and Respondents'

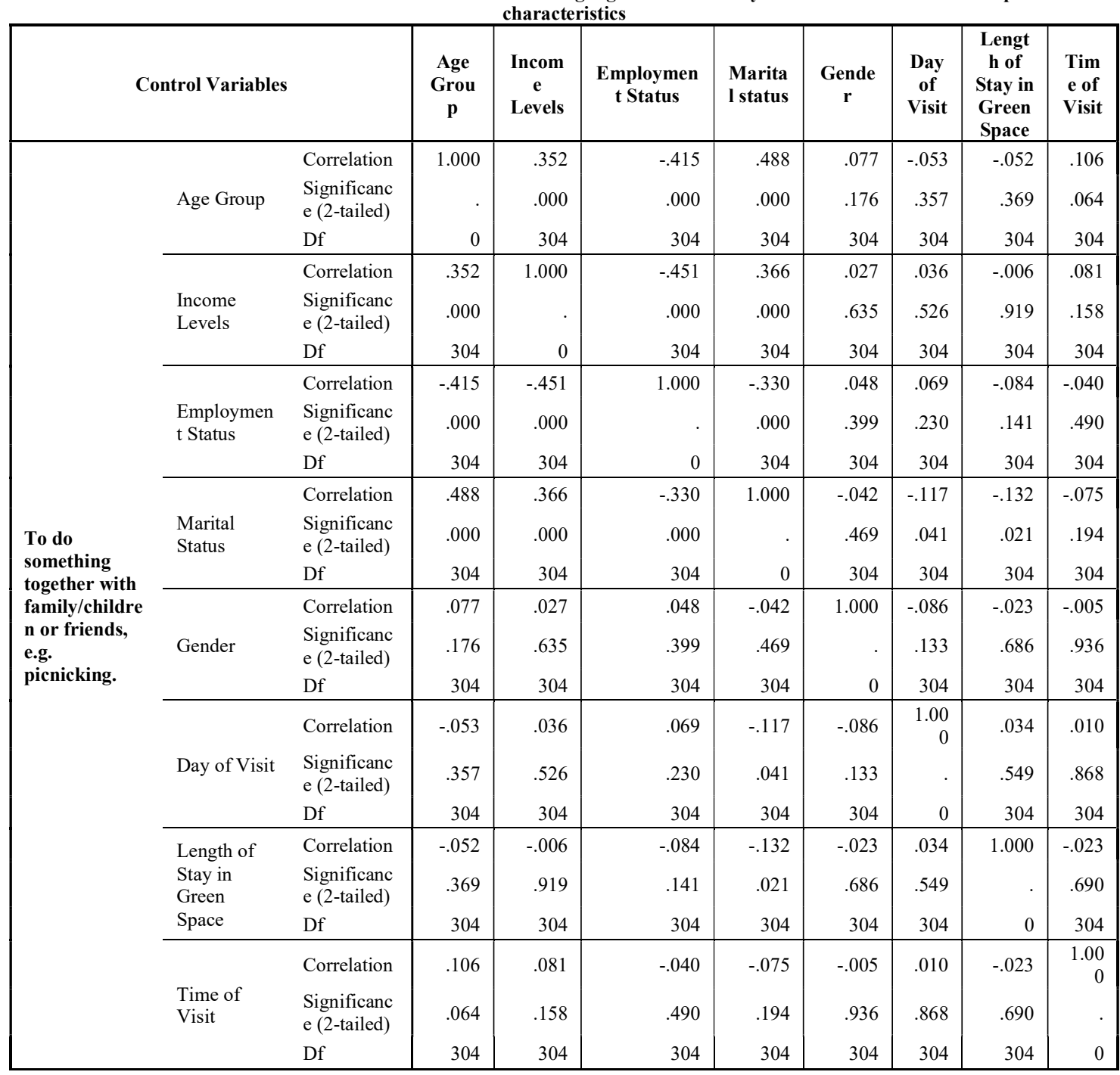


Table 4B: Correlations between Users' Motive 'To socialise at organised events (parties, weddings, funerals, etc.)' and Respondents' characteristics

\begin{tabular}{|c|c|c|c|c|c|c|c|c|c|c|}
\hline \multicolumn{3}{|c|}{ Control Variables } & \multirow{2}{*}{$\begin{array}{c}\begin{array}{c}\text { Age } \\
\text { Group }\end{array} \\
1.000\end{array}$} & \multirow{2}{*}{$\begin{array}{r}\begin{array}{c}\text { Income } \\
\text { Levels }\end{array} \\
.355\end{array}$} & \multirow{2}{*}{$\begin{array}{r}\begin{array}{c}\text { Employment } \\
\text { Status }\end{array} \\
-.421\end{array}$} & \multirow{2}{*}{$\begin{array}{r}\begin{array}{c}\text { Marital } \\
\text { status }\end{array} \\
.487\end{array}$} & \multirow{2}{*}{$\begin{array}{r}\text { Gender } \\
.082\end{array}$} & \multirow{2}{*}{$\begin{array}{c}\begin{array}{c}\text { Day } \\
\text { of } \\
\text { Visit }\end{array} \\
-.047\end{array}$} & \multirow{3}{*}{$\begin{array}{c}\begin{array}{c}\text { Length } \\
\text { of Stay } \\
\text { in }\end{array} \\
\text { Green } \\
\text { Space } \\
-.066 \\
.249\end{array}$} & \multirow{3}{*}{$\begin{array}{c}\begin{array}{c}\text { Time } \\
\text { of } \\
\text { Visit }\end{array} \\
.104 \\
.069\end{array}$} \\
\hline \multirow{24}{*}{$\begin{array}{l}\text { To } \\
\text { socialise at } \\
\text { organised } \\
\text { events } \\
\text { (parties, } \\
\text { weddings, } \\
\text { funerals, } \\
\text { club } \\
\text { meetings, } \\
\text { picnics, old } \\
\text { school } \\
\text { reunion, } \\
\text { public } \\
\text { events, } \\
\text { etc.). }\end{array}$} & \multirow{3}{*}{ Age Group } & Correlation & & & & & & & & \\
\hline & & $\begin{array}{l}\text { Significance } \\
\text { (2-tailed) }\end{array}$ & • & .000 & .000 & .000 & .153 & .408 & & \\
\hline & & Df & 0 & 304 & 304 & 304 & 304 & 304 & 304 & 304 \\
\hline & \multirow{3}{*}{$\begin{array}{l}\text { Income } \\
\text { Levels }\end{array}$} & Correlation & .355 & 1.000 & -.450 & .366 & .025 & .040 & -.004 & .084 \\
\hline & & $\begin{array}{l}\text { Significance } \\
\text { (2-tailed) }\end{array}$ & .000 & . & .000 & .000 & .660 & .490 & .949 & .142 \\
\hline & & Df & 304 & 0 & 304 & 304 & 304 & 304 & 304 & 304 \\
\hline & \multirow{3}{*}{$\begin{array}{l}\text { Employment } \\
\text { Status }\end{array}$} & Correlation & -.421 & -.450 & 1.000 & -.332 & .054 & .066 & -.095 & -.046 \\
\hline & & Significance & .000 & .000 & . & .000 & .351 & .251 & .099 & .428 \\
\hline & & Df & 304 & 304 & 0 & 304 & 304 & 304 & 304 & 304 \\
\hline & \multirow{3}{*}{$\begin{array}{l}\text { Marital } \\
\text { Status }\end{array}$} & Correlation & .487 & .366 & -.332 & 1.000 & -.041 & -.118 & -.131 & -.075 \\
\hline & & $\begin{array}{l}\text { Significance } \\
\text { (2-tailed) }\end{array}$ & .000 & .000 & .000 & . & .470 & .040 & .022 & .188 \\
\hline & & Df & 304 & 304 & 304 & 0 & 304 & 304 & 304 & 304 \\
\hline & \multirow{3}{*}{ Gender } & Correlation & .082 & .025 & .054 & -.041 & 1.000 & -.082 & -.017 & .000 \\
\hline & & $\begin{array}{l}\text { Significance } \\
\text { (2-tailed) }\end{array}$ & .153 & .660 & .351 & .470 & . & .151 & .768 & .997 \\
\hline & & Df & 304 & 304 & 304 & 304 & 0 & 304 & 304 & 304 \\
\hline & \multirow{3}{*}{ Day of Visit } & Correlation & -.047 & .040 & .066 & -.118 & -.082 & 1.000 & .017 & .011 \\
\hline & & $\begin{array}{l}\text { Significance } \\
\text { (2-tailed) }\end{array}$ & .408 & .490 & .251 & .040 & .151 & . & .770 & .854 \\
\hline & & Df & 304 & 304 & 304 & 304 & 304 & 0 & 304 & 304 \\
\hline & \multirow{3}{*}{$\begin{array}{l}\text { Length of } \\
\text { Stay in } \\
\text { Green Space }\end{array}$} & Correlation & -.066 & -.004 & -.095 & -.131 & -.017 & .017 & 1.000 & -.036 \\
\hline & & $\begin{array}{l}\text { Significance } \\
\text { (2-tailed) }\end{array}$ & .249 & .949 & .099 & .022 & .768 & .770 & & .535 \\
\hline & & Df & 304 & 304 & 304 & 304 & 304 & 304 & 0 & 304 \\
\hline & \multirow{3}{*}{$\begin{array}{l}\text { Time of } \\
\text { Visit }\end{array}$} & Correlation & .104 & .084 & -.046 & -.075 & .000 & .011 & -.036 & 1.000 \\
\hline & & $\begin{array}{l}\text { Significance } \\
\text { (2-tailed) }\end{array}$ & .069 & .142 & .428 & .188 & .997 & .854 & .535 & \\
\hline & & Df & 304 & 304 & 304 & 304 & 304 & 304 & 304 & 0 \\
\hline
\end{tabular}


Table 4C: Correlations between Users' Motives 'To rest, relax and reduce stress by escaping from the hustle and bustle of the city' and Respondents' characteristics

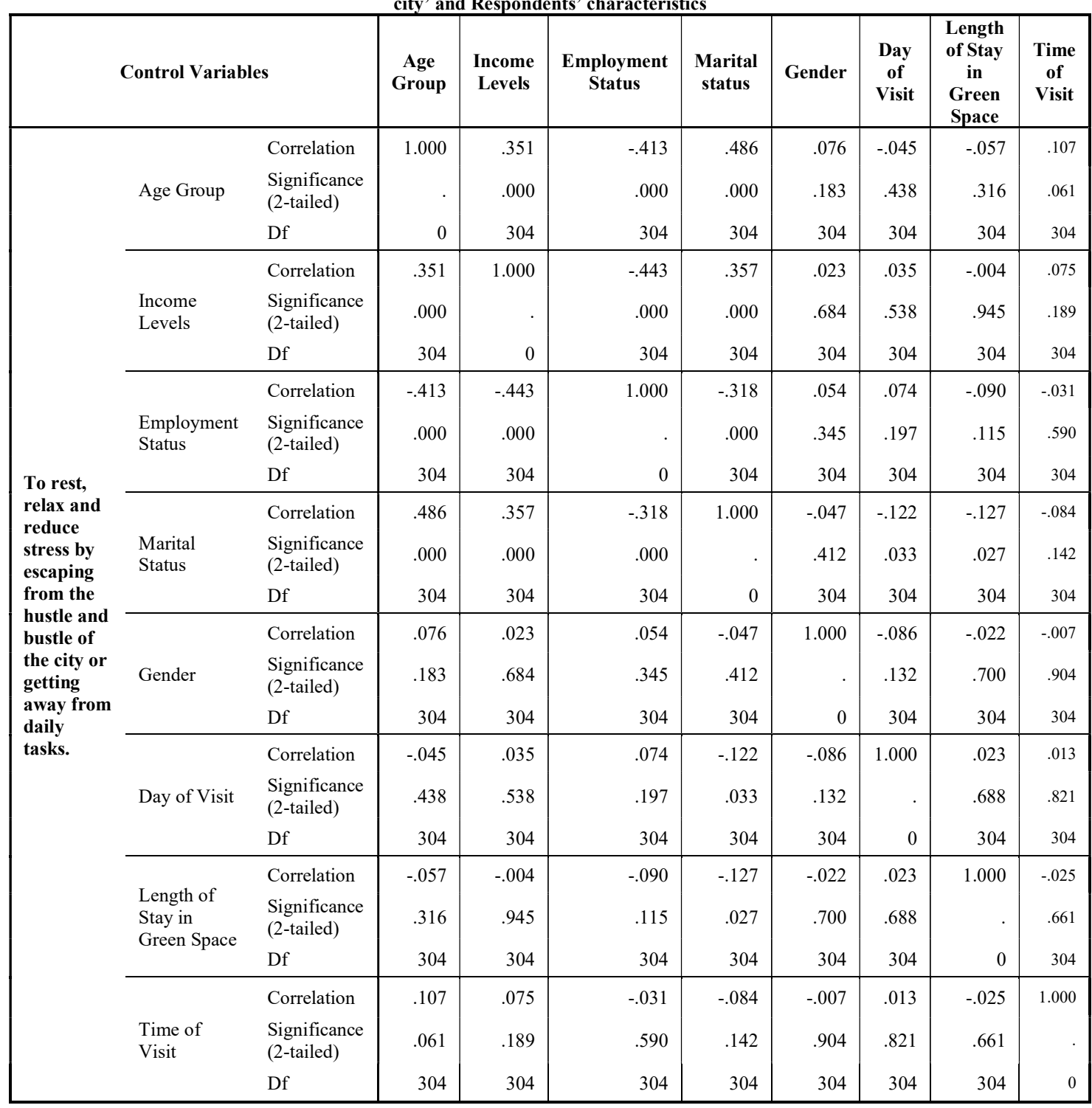


Table 4D: Correlations between Users spirituality Motive 'To participate in religious activities such as prayers, retreats, worshipping, etc.' Respondents' characteristics

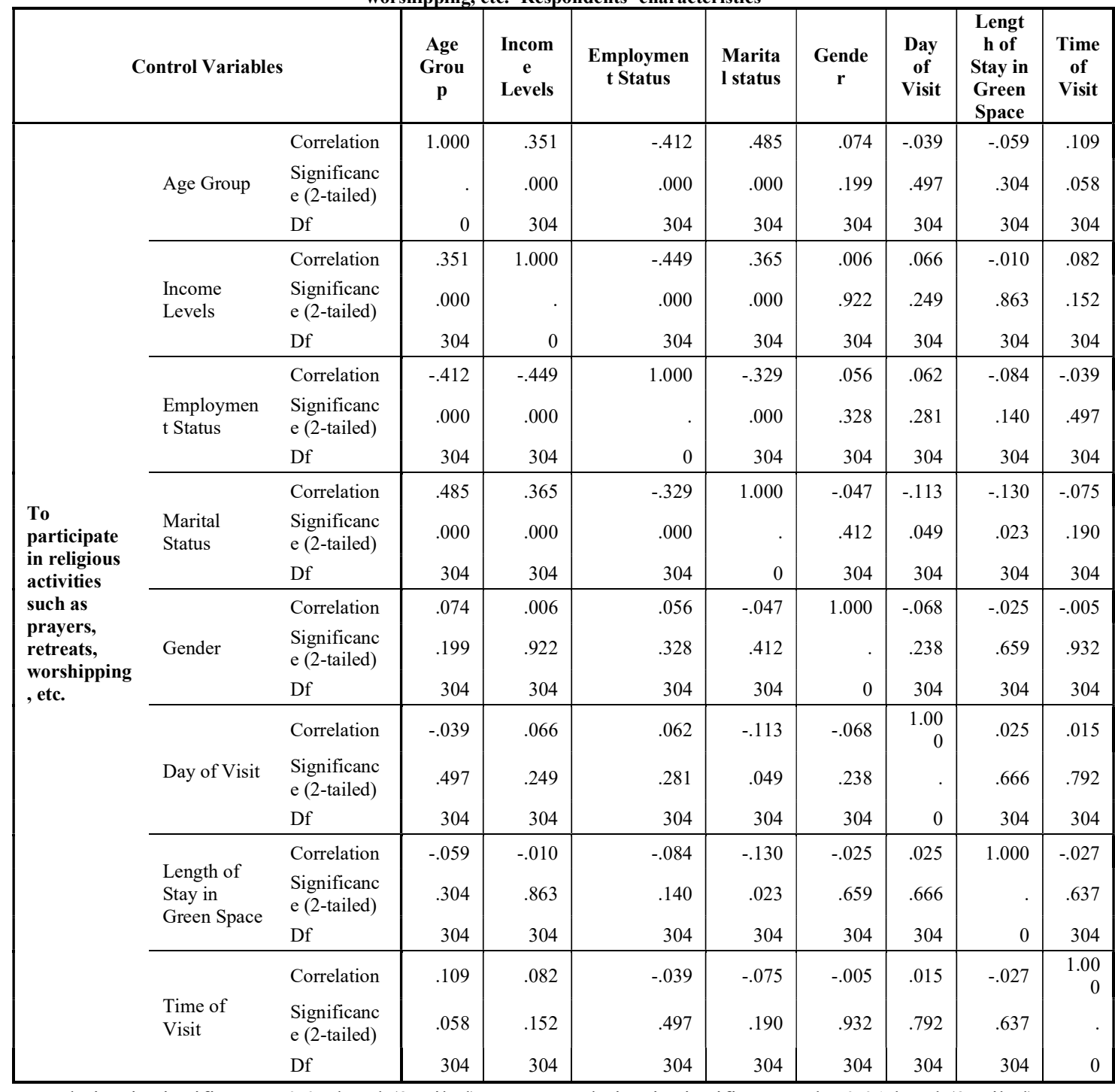

*Correlation is significant at 0.05 level (2 tailed) $\quad * *$ Correlation is significant at the 0.01 level ( 2 tailed)

The four (4) primary motivations for visiting urban green spaces derived in this study are categorised into "socialising", "mental wellbeing or restitution" and "spirituality". These results largely support previous studies by Kuo et al. (1998), Chiesura (2004), Schipperrijn et al. (2010) and Peschardt et al. (2012). In comparison, literature points to "mental wellbeing or rest and restitution" as the most important reason for visiting urban green spaces in Europe (Thompson, 2002; Chiesura, 2004; Schipperijn et al., 2010; Peschardt et al., 2012), but the findings of this study show that "socialising" is the primary motive for visiting green spaces in Accra. "Socialising" in this context relates to "to do something together with family or friends' and "to socialise at organised events", which relate directly to the traditional ways Ghanaians commonly use outdoor space. In Ghana, open-air spaces, especially those with trees and lawns, are typically used for interactive social activities that stimulate social cohesion and foster family, neighbourhood and community ties, which confirms findings by Kuo et al. (1998), Dunnett et al. (2002) and Swanwick et al. (2002). These outdoor activities include picnicking, wedding receptions, parties, funerals, fun games, club meetings, organised commercial, religious and public events, musical concerts and promotional events.

"Mental wellbeing or restitution", which includes "to rest, relax and reduce stress by escaping from the hustle and bustle of the city or getting away from daily tasks", is the third primary motive of green space users in Accra, and 
a common aim of users in all urban contexts. The results of the study also show that despite the tangible benefits of improved health from physical activities in green spaces, "to sport or to exercise" is not a significant motive of urban nature users in Accra, similar to Chiesura's (2004) findings in the Netherlands. In the case of Accra, none of the green spaces has the features and infrastructure for vigorous activities, such as trails, landscaped walkways, drives, bike lanes, tennis courts, basketball and volleyball courts, etc. In contrast, reasons relating to active sporting and vigorous activities, such as cycling, walking, running, swimming, jogging and aerobics, are the predominant motivations in parks users in the USA (Lee \& Kim, 2015).

The third primary motivations for visiting urban green spaces in Accra the study discovered relates to "spirituality". In Accra, many people visit the green areas, especially the Achimota Forest, to participate in religious activities such as meditation, prayers, retreats and worshipping. The study ascertained that the average annual total number of visitors to the Achimota Forest was 263,160, comprising mainly church groups. As postulated by Chiesura (2004) and Roos et al. (2011), urban greenery provides serene milieus for general spiritual experiences, including feeling closer to God. Hindus, for instance, attach spiritual importance to trees coconuts, mangoes and neems, and their religious shrines are usually located within gardens regarded as places of sacred values (Thaman, 1987). However, the extent of the noisy environment the group spiritual prayer sessions create in green spaces in Accra, especially in the Achimota Forest, is contradictory to the individual visitor's reflection, meditation and contemplation within the natural ambience in European and American urban green spaces.

Overall the findings are consistent with previous research results which concluded that socio-cultural backgrounds of users influence their motives for visiting urban green spaces (McFarlane \& Boxall, 2003; Sasidharan et al. 2005; Snape \& Binks, 2008). Therefore, the users' motivations for visiting urban green areas and the activities they engage in the spaces discovered from this research, must be considered by the city's planners and urban designers in the design and management of urban green spaces in order to fulfil the public's demands and expectations of urban green areas.

\subsection{Factors influencing the Public's Perception of Quality and Usage of Green Spaces}

The respondents rated seventeen (17) factors that influence their perception of the quality of the city's green spaces and their decision to make use of the areas on a 5-point Likert Scale. Based on a four-level classification of the scores, i.e. 1.00.-2.00, 2.01-3.00, 3.01-4.00 and 4.01-5.00, the resultant mean and standard deviation of each variable are as presented in Table 5.

Out of seventeen (17) identified factors, "availability of amenities, such as washrooms/toilets, lighting, water supply, eatery, seats or pavilions, rubbish bins and waste disposal", was cited by the respondents as the topmost impact on their perception of the quality and decision to visit the city's green spaces, with a mean score of 4.17. The next four most important factors were the "physical characteristics of space" (4.16), "safety concerns relating to the control of the crowd, noise, crime, illicit activities" (4.07), "adequacy and conditions of facilities for recreation" (4.01) and "sanitary conditions" (3.98). Factors regarded by the respondents as less important in influencing the use of green spaces in Accra were, "entrance or user fees" and "size of green space", with mean scores of 3.33 and 3.30 respectively. With the lowest mean score of 1.93 , "distance from home to available urban green spaces", was considered as the least significant factor influencing users' perception of the quality and use of urban green spaces in Accra. 
Table 5: Descriptive Statistics of Factors influencing People's Perception of Quality and Usage of Green Spaces in Accra

\begin{tabular}{|c|c|c|c|c|}
\hline $\mathbf{S} / \mathbf{N}$ & $\begin{array}{l}\text { Factors influencing people's perception of } \\
\text { quality and usage of Green Spaces in Accra }\end{array}$ & $\mathbf{N}$ & Mean & $\begin{array}{c}\text { Std. } \\
\text { Deviation }\end{array}$ \\
\hline A. & $\begin{array}{l}\text { Physical characteristics of space (variety of } \\
\text { spaces, serene landscape, greenery and mature } \\
\text { trees) }\end{array}$ & 400 & & 0.910 \\
\hline B. & Size of Green Space. & 400 & 3.30 & 1.221 \\
\hline C. & $\begin{array}{l}\text { Public education and information about the green } \\
\text { spaces. }\end{array}$ & 400 & & 1.014 \\
\hline D. & $\begin{array}{l}\text { The neighbourhood a particular green space is } \\
\text { located }\end{array}$ & 400 & 3.53 & 1.130 \\
\hline E. & Presence of drug and alcohol users. & 400 & 3.46 & 1.184 \\
\hline F. & $\begin{array}{l}\text { Proximity to public transportation transit and } \\
\text { pedestrian circulation systems. }\end{array}$ & 400 & & 1.189 \\
\hline G. & Entrance fees/user fees. & 400 & 3.33 & 1.310 \\
\hline H. & $\begin{array}{l}\text { Facilities and activities green space is designed } \\
\text { for, and management or coordination of the } \\
\text { activities within. }\end{array}$ & 400 & & 1.064 \\
\hline I. & $\begin{array}{l}\text { Availability of facilitators, hospitality, sense of } \\
\text { welcoming of green space, signage and } \\
\text { regulations. }\end{array}$ & 400 & & 1.055 \\
\hline $\mathrm{K}$. & Facilities for active sports and exercising. & 400 & 3.69 & 1.178 \\
\hline L. & Provision for the aged and the disabled & 400 & & 1.156 \\
\hline M. & $\begin{array}{l}\text { Safety concerns (Security, control of crowd, noise } \\
\text { crime, outlawed/illicit activities) }\end{array}$ & 400 & & 1.126 \\
\hline N. & $\begin{array}{l}\text { Sanitary conditions (garbage, litter, graffiti and } \\
\text { dog mess) }\end{array}$ & 400 & & 1.189 \\
\hline O. & $\begin{array}{l}\text { Availability of features (sculptures, water } \\
\text { bodies/fountains, varied landscape and } \\
\text { topography). }\end{array}$ & 400 & & 1.119 \\
\hline P. & $\begin{array}{l}\text { Adequacy and conditions of facilities for } \\
\text { recreation, children playgrounds and equipment. }\end{array}$ & 400 & 4.01 & 0.931 \\
\hline Q. & $\begin{array}{l}\text { Distance from home to available urban green } \\
\text { spaces. }\end{array}$ & 400 & 1.93 & 1.162 \\
\hline $\mathrm{R}$. & $\begin{array}{l}\text { Availability and conditions of amenities } \\
\text { (washrooms/toilets, lighting, water supply, eatery, }\end{array}$ & 400 & 17 & 0.964 \\
\hline
\end{tabular}




\begin{tabular}{|l|l|l|l|c|}
\hline S/N & $\begin{array}{c}\text { Factors influencing people's perception of } \\
\text { quality and usage of Green Spaces in Accra }\end{array}$ & N & Mean & $\begin{array}{c}\text { Std. } \\
\text { Deviation }\end{array}$ \\
\hline $\begin{array}{l}\text { seats or pavilions, rubbish bins and waste } \\
\text { disposal). }\end{array}$ & & & \\
\hline Valid N (listwise) & 400 & & \\
\hline
\end{tabular}

Source: Authors' Fieldwork, 2020

The findings reflect two broad dimensions: the "management of facilities" and the "naturalness" of the spaces. The "management of facilities" was the most significant quality indicator. This component comprises three critical attributes of the green spaces in Accra: (1) the nature and condition of comfort facilities such as drinking fountains, pavilions, picnic seats and tables, washrooms or toilets, lighting, eateries, safety and security, (2) sanitary conditions like garbage, litter, graffiti and dog mess, and (3) the adequacy and conditions of facilities for recreation such as children's playgrounds and equipment. Relating to "naturalness", the attributes affecting people's opinion on the quality and use of green spaces are the variety of spaces, topography, and vegetation lushness. These categories of indicators influencing people's perception of the quality and use of the spaces both positively and negatively, confirm the conclusions of previous research by Dunnett et al. (2002); Jim \& Chen (2006); McCormack et al. (2010).

The negative aspects prevailing in urban green spaces in Accra relate to poor maintenance of facilities and uncleanliness of the spaces, which reinforce the assertion by McCormack et al. (2010) that these conditions "negatively affect aesthetics, perceptions of safety, functionality, and the overall perceptions" of the quality of the green spaces (p. 723). Conversely, well-maintained facilities and tidy environments with profuse vegetation create the required ambience and serenity levels for positive discernments of the areas and increased visitation by the public (Jim \& Chen, 2006).

Other factors affecting people's options about urban greens spaces in Accra which are consistent with literature include, accessibility, safety from crime, and control of crowd, noise, crime and outlawed or illicit activities (McCormack et al., 2010), provisions for the aged and the disabled (Jim and Chen, 2006). However, features such as sculptures, pedestrian pathways, lakes and ponds, fountains and mazes identified by Gobster (2002) and McCormack et al. (2010) as elements that affect people's perception of urban green spaces, were not available in Accra's green areas. Similarly, the characteristics of municipal green space facilities for sports and physical activities such as trails, athletic ovals and swimming pools, which literature refers to as significant indicators for quality and visitation (Zhang et al., 2013), were deficient in all the green areas in the city. It is, therefore, not surprising that active sporting and physical activities were not prominent in the users' motives for visiting green spaces in Accra. In summary, the broad thematic factors that influence peoples' perception of the quality and use of Accra's green spaces relate to the settings of the physical environments, availability and conditions of facilities for recreation and comfort, sanitation, security and safety, and adequacy of greenery within the spaces.

\section{Conclusion}

The research findings revealed the significant motives of visitors to the existing green spaces and the physical attributes of the spaces that influence the public's perception of quality and patronage of the areas within a distinct context that had not been previously researched. Thoughtful consideration of these expectations and aspirations and the motivation of people for green space visitations could contribute to the creation of community-specific, relevant and inclusive urban green spaces in Ghana.

The existing urban green spaces are occasionally used mainly during the weekends and public holidays between mid-morning and mid-afternoons with a majority of visitors spending between one and six hours in the green spaces. This pattern of usage reflects the general activities undertaken within the green areas, which are predominantly recreational, leisure and social activities, such as organised public events, group recreation, religious activities, family picnics, etc., that take place during these periods. These activities conform with the Ghanaian traditional functional and social activities that connect family and community members and which customarily take place within courtyards and open natural environments. 
The four key user motives for visiting urban green areas in Accra discovered are as follows: "to do something together with family/children or friends, e.g. picnicking", "to socialise at organised events, such as parties, weddings, funerals, club meetings, picnics, public events", "to rest, relax and reduce stress, by getting away from daily tasks", and "to participate in religious activities such as prayers, retreats, worshipping". These motives are summarised into "socialising", "mental wellbeing or restitution" and "spirituality". The research also identified green spaces' physical features, conditions of facilities, sanitation and security concerns as the significant facilitators and constraints that impact on the public's perception of the quality and usage of green spaces in Accra.

The findings on the factors that impact users' opinion on the physical features of urban greenery are consistent with existing literature. However, the outcome of this research has revealed a thought-provoking perspective for future research on "spirituality" as significant users' motivation for visiting urban green spaces since the "spirituality" factor is deficient in literature. The conclusions of this study, therefore, form a foundation for filling the knowledge gap in urban design, landscape architecture, and green space planning and design. It is also critical for policy-makers, urban designers and landscape architects to understand the vital motives of potential users and their preferred activities and other factors that influence the use of green spaces. Understanding these issues is not only crucial for increasing green space usage but also for policy-makers, park managers and the metropolitan authorities to recognise and plan for these factors in order to improve on the reliability of planning and development of urban green spaces in Ghana and other developing countries.

\section{References}

African Green City Index. (2011). Assessing the environmental performance of Africa's major cities. München, Germany: Siemens AG, Corporate Communications and Government Affairs.

Apt, N. A. (2002). Accra in the 21st Century: visions from the Crystal Ball of a Sociologist. In \&. Adi-Dako, Ralph Mills-Tettey and Koranteng (Ed.), Vision of the City: Accra in the 21st Century (pp. 39-47). Accra, Ghana: Woeli Publishing Services for Goethe-Institut Inter Nations.

Arku, G., Yeboah, I. E.A., and Nyantakyi-Frimpong, H. (2016). 'Public parks as an element of urban planning: a missing piece in Accra's growth and development'. Local Environment - The International Journal of Justice and Sustainability, pp. 1-16.

Arnberger, A. (2006). 'Recreation use of urban forests: an inter-area comparison'. Urban Forestry and Urban Greening, 4, pp. 135-144.

Aspinall, P., Bell, S., Findlay, C., Wherrett, J., and Travlou, P. (2004). Open space and social inclusion: Local woodland use in Central Scotland. United Kingdom. Forestry Commission.

Beaney, K. (2009). Green spaces in the urban environment: uses, perceptions and experiences of Sheffield city centre residents (Doctoral dissertation, University of Sheffield).

Bertram, D. (2007). Likert scales November 2 (2007): 2013. Retrieved November 26, 2019, from Likert Scale \lickurt\, n.: http://poincare.matf.bg.ac.rs/ kristina/topic-dane-likert.pdf

Birchall, J. (2014). Sampling and Samples. Retrieved from: Market Research World. http://www.marketresearchworld.net/content/view/23/41/1/2/

Byrne, J. and Sipe, N. (2010). Green and open space planning for urban consolidation - A review of the literature and best practice. Brisbane: Urban Research Program Issues Paper 11. Retrieved July 27, 2020, from http://www.researchgate.net/profile/Jason_Byrne2/publication/47375644_Green_and_open_space_plan ning_for_urban_consolidation_A_review_of the_literature_and_best_practice/links $/ 0 \mathrm{fcfd} \overline{5} 0 \mathrm{~b} 42 \mathrm{a} 34 \mathrm{be}$ 2b0000000.pdf

Byrne, J. and Wolch, J. (2009). 'Nature, race, and parks: past research and future directions for geographic research'. Progress in Human Geography, 33(6), pp. 743-765.

Central Park Conservancy. (2011). Report on the public use of Central Park. New York, NY: Central Park Conservancy.

Chiesura, A. (2004). 'The role of urban parks for the sustainable city'. Landscape and Urban Planning, 68, pp. $129-138$.

Coley, R., Kuo, F., and Sullivan, W. (1997). 'Where does community grow? The social context created by nature in urban public housing'. Environment and Behaviour, 29(4), pp. 468-494.

Cooper, D.R., and Schindler, P.S. (2006). Business Research Methods. Boston, Mass.: McGraw-Hill. 
Dunnett, N., Swanwick, C., and Wooley, H. (2002). Improving urban parks, play areas and green spaces. London: Department for Transport, Local Government and the Regions.

Gaodi, X., Wenhua L, Xiao Y, Zhang B, Chunxia L, Kai A, Wang J, Kang X and Wang J. (2010). 'Forest ecosystem services and their values in Beijing'. Chinese Geographical Science, 20, pp. 51-58.

Ghana Statistical Service. (2013). 2010 Population and Housing Census - National Analytical Report. Accra, Ghana: Ghana Statistical Service.

Ghana Statistical Service. (2014). 2010 Population and Housing Census - District Analytical Report (Accra Metropolitan). Accra: Ghana Statistical Service.

Henderson, K. A. and Bialeschki, M. D. (2005). 'Leisure and active lifestyles: Research reflections'. Leisure Science, 27, pp. 355-365

Hoet, C., Sasidharan, V., Elmendorf, W., Wilits, F., Graefe, A. and Godbey, G. (2005). 'Gender and ethnic variations in urban park preferences, visitation, and perceived benefits'. Journal of Leisure Research, 37, pp. 281-306.

Humpel, N., Owen, N., and Leslie, E. (2002). 'Environmental factors associated with adults' participation in physical activity'. American Journal of Preventive Medicine, 22, pp. 188-199.

Hussain, N. (2014). Use and experience in two recreational forests in Selangor State, Malaysia: the impact of age, gender and ethnicity. Doctoral Dissertation. University of Sheffield.

Hussain, N., and Abdul Mohit, M. (2005). 'An analysis of the use of Local Parks based on park users' survey in selected Local Parks of Kuala Lumpur'. Proceedings of ASEAN Postgraduate Seminar, 2005. Faculty of Built Environment, University Malaya.

Irvine, K. N., Warber, S. L., Devine-Wright, P., and Gaston, K. J. (2013). 'Understanding urban green space as a health resource: A qualitative comparison of visit motivation and derived effects among park users in Sheffield, UK'. International Journal of Environmental Research and Public Health, 10(1), pp. 417-442.

Jim, C. and Chen, W.Y. (2006). 'Recreation-amenity use and contingent valuation of urban green spaces in Guangzhou, China'. Landscape and Urban Planning, 75, pp. 81-96.

Jonker, M. F., van Lenthe, F. J., Donkers, B., Mackenbach, J. P., and Burdorf, A. (2014). 'The effect of urban green on small-area (healthy) life expectancy'. Journal of Epidemiology and Community Health, 68, pp. 999-1002.

Jorgensen, A. and Anthopoulou, A (2007). 'Enjoyment and fear in urban woodlands - Does age make a difference'? Urban Forestry and Urban Greening, 6, pp. 267-278.

Kay, T. (2000). 'Leisure, gender and family: The influence of social policy'. Leisure Studies, 19, pp. $247-265$.

Kemperman, A. and Timmermans, H.J.P. (2008). 'Influence of socio-demographic and residential environment on leisure activity participation'. Leisure Sciences, 30, pp. 306-324.

Kish, L. (1965). Survey Sampling. New York: John Wiley and Sons, Inc. Retrieved November 9, 2019, from https://scholar.google.com/scholar?hl=en\&q=L.+Kish+\%281965\%29+Survey+Sampling.+John+Wiley + and + Sons $\% 2 \mathrm{C}+$ Inc. $\% 2 \mathrm{C}+\mathrm{New}+$ York.\&btnG=\&as_sdt=1\%2C5\&as_sdtp=

Kuo, F.E., Bacaioca, M., and Sullivan, W.C. (1998). 'Transforming inner-city landscapes: trees, sense of safety, and preferences'. Environment and Behaviour, 1(30), pp. 28-59.

Lee, Y. and Kim, K. (2015). 'Attitudes of Citizens towards Urban Parks and Green Spaces for Urban Sustainability: The Case of Gyeongsan City, Republic of Korea'. Sustainability, 7, pp. 8240-8254.

List, D. (2005). Know your audience. A Practical Guide to Media Research - Audience Dialogue. Wellington, New Zealand: Original Books. Retrieved January 16, 2020, from http://www.audiencedialogue.net/kya2c.html

Makworo, M. and Mireri, C. (2011). 'Public open spaces in Nairobi City, Kenya, under threat'. Journal of Environmental Planning and Management, 54(8), pp. 1107-1123. doi:10.1080/09640568.2010.549631

McCormack, G. R., Rock, M., Toohey, A. M., and Hignell, D. (2010). 'Characteristics of urban parks associated with park use and physical activity: A review of qualitative research'. Health and Place, 16(4), pp. 712726. 
McFarlane, B. L. and Boxall, P. C. (2003). 'The role of social psychological and social structural variables in environmental activism: an example of the forest sector'. Journal of Environmental Psychology, 23, pp. 79-87.

Mitra, A. and Lankford, S. (1999). Research Methods in Park, Recreation and Leisure Services. Champaign, IL.: Sagamore.

Nielson, T.S. and Hansen, K.B. (2006). 'Nearby nature and green areas encourage outdoor activities and decrease mental stress'. CAB Reviews: Perspectives in Agriculture, Vertinery Science, Nutrition and Natural Resources, 1, (059).

Nieuwenhuijsen, M. J., Kruize, H., Gidlow, C., Andrusaityte, S., Antó, J. M., Basagaña, X., Cirach, M., Dadvand, P., Danileviciute, A., Donaire-Gonzalez, D. and Garcia, J. (2014). 'Positive health effects of the natural outdoor environment in typical populations in different regions in Europe (PHENOTYPE): A study programme protocol'. BMJ Open, 4(4), e004951.

Özgüner, H. (2011). 'Cultural Differences in attitudes towards Urban Parks and Green Spaces'. Landscape Research, 36(5), pp. 599-620.

Peschardt, Karin K., Schipperijnb, J. and Stigsdotte, U.K. (2012). 'Use of small public urban green spaces'. Urban Forestry and Urban Greening, 11, pp. 235-244. doi:10.1016/j.ufug.2012.04.002

Quagraine, V. K. (2011). 'Urban Landscape Depletion in the Kumasi Metropolis'. In K. K. Adarkwa (Ed.), Future of the Tree - Towards Growth and Development of Kumasi (pp. 212-233). Kumasi: University Printing Press, Kwame Nkrumah University of Science and Technology.

Qureshi, S., Breuste, J. H. and Jim, C. Y. (2013). 'Differential community and the perception of urban green spaces and their contents in the megacity of Karachi, Pakistan'. Urban Ecosystems, 16(4), pp. 853-870.

Roos, V., Coetzee, H., \& Puren, K. (2011). 'People's experiences in a natural environment in the Vredefort Dome, South Africa: implications for spatial development'. Tydskrif vir Geesteswetenskappe, 51(1), pp. 68-85.

Sasidharan, V., Willits, F. and Godbey, G. (2005). 'Cultural differences in urban recreation patterns: An examination of park usage and activity participation across six population subgroups'. Managing Leisure, 10, pp. 19-38.

Schipperijn, J.E., Ola, E., Ulrika, K.S., Mette, T., Bentsen, P., Kamper-Jorgensen, F. and Randrup, T.B. (2010). 'Factors influencing the use of green space: Results from a Danish national representative survey'. Landscape and Urban Planning, 95, pp. 130-137.

Shin, W.S., Jaakson, R. and Kim, E.I. (2001). 'Benefits-based analysis of visitor use of Sorak-San National Park in Korea'. Environmental Management, 28(3), pp. 413-419.

Snape, R. and Binks, P. (2008). 'Re-thinking sport: physical activity and health living in British South Asian Muslim communities'. Managing Leisure, 13(1), pp. 23-35.

Swanwick, C., Dunnett, N. and Woolley, H. (2003). 'Nature, role and value of green space in towns and cities: An overview'. Built Environment, 29(2), pp. 94-106.

Thaman, R. (1987). Urban Agroforestry: 'The Pacific islands and beyond'. Urban Forestry: Cities, Trees and People - An International Journal of the Forestry and Food Industries, 39(155), pp. 2-13.

Thompson, W. (2002). 'Urban open space in the 21st Century'. Landscape and urban planning, 60(2), pp. 59-72.

Thompson, W. C., Aspinall, P., Bell, S., and Findlay, C. (2005). 'It gets you away from everyday life": Local woodlands and community use-What makes a difference'? Landscape Research, 30(1), pp. 109-146.

Town and Country Planning Department. (2001). Managing open space development in Accra. Accra, Ghana: Ministry of Local Government and Rural Development.

Ulrich, R. (1984). 'View through a window may influence recovery from surgery'. Science, 224(4647), pp. 420421.

UN-HABITAT. (2014). The state of African Cities 2014: Reimaging sustainable urban transitions. Nairobi, Kenya: UN-HABITAT.

Valentine, G. (1991). 'Women's fear and the design of public space'. Built Environment, 16, pp. 288-303.

Virden, R. J. and Walker, G. J. (1999). 'Ethnic/racial and gender variations among meanings given to, and preference for; the natural environment'. Leisure Sciences, 21, pp. 219-239. 
Ward, C. D., Parker, C. M., and Shackleton, C. M. (2010). 'The use and appreciation of botanical gardens as urban green spaces in South Africa'. Urban Forestry and Urban Greening, 9(1), pp. 49-55.

William, L.H. (1975). Statistics: Probability, Inference and Decision. (2nd Ed.). New York: Holt, Rinehart and Winston.

Yansaneh, I. S. (2005). 'Overview of sample design issues for household surveys in developing and transition countries. In Glewwe', P. (Ed.) Household Sample Surveys in Developing and Transition Countries (pp.11-34). The United Nations Department of Economic and Social Affairs (UN-DESA). Retrieved January 16, 2020, from http://unstats.un.org/unsd/hhsurveys/pdf/Chapter_2.pdf

Zhang, H., Chen, B., Sun, Z., and Bao, Z. (2013). 'Landscape perception and recreation needs in urban green space in Fuyang, Hangzhou, China'. Urban Forestry and Urban Greening, 12(1), pp. 44-52. 